\title{
An Analytical Study of the Strategies Used in Translating Trump's Tweets into Arabic
}

\author{
Mohammed Juma Zagood \\ Department of Translation Studies \\ College of Humanities and Social Sciences, UAE University \\ Al Ain, UAE
}

\begin{abstract}
It is increasingly interesting that one of the new focuses of translation studies is the translatability of the short posts on social media. Research in translating social media posts has recently received a greater attention among translation studies specialists. This paper looks firstly at Twitter as a growing social media networking and its language and, secondly, shedding some light on translation strategies used in translating English tweets into Arabic. Posts on Twitter, 'tweets,' by well-known figures are followed, translated, and reposted in other languages every day. Strategies used by Arab translators vary depending on the importance of the tweet as well as the ideology of the translator and the institutions they work for. This paper, therefore, investigates the translation strategies adopted by the Arab online news agencies, mentioned later, on their web pages in translating some tweets posted by the American President, Donald Trump in his first month of presidency. The analysis draws on Vinay and Darbelnet's (1958/1995) model and Nida's (1964) translation strategies.
\end{abstract}

Keywords: Online news, social media, translation strategies, translation model, Twitter

Cites as: Zagood, M. Z (2019). An Analytical Study of the Strategies Used in Translating Trump's Tweets into Arabic. Arab World English Journal for Translation \& Literary Studies, 3 (1) 22-34 . DOI: http://dx.doi.org/10.24093/awejtls/vol3no1.2 
AWEJ for Translation \& Literary Studies Volume, 3 Number 1. February 2019

An Analytical Study of the Strategies Used in Translating Trump's Tweets Zagood

\section{Introduction}

Social media are computer-mediated technologies that allow users to exchange information, ideas, thoughts, etc., express their feelings towards different topics and/or show their political opinions. Social media facilitate the online networking by connecting users wherever they are with each other. Followers from different countries around the globe can see what others write and post on their timelines. Social media depends entirely on the availability of access to the internet. They are the search engines that are considered significant factors in speeding up online news posts and readers finding news stories which increase the readers' patterns of online news, (Organization for Economic Co-operation and Development, 2010). The social media websites include Facebook, WhatsApp, Instagram, Twitter, LinkedIn, Viber, WeChat, etc. According to some sources; (The Economic Times 2010 quoted in Barton and Lee, (2013) as of April 2010; there is over 100 million registered user accounts had been created on Twitter. Another statistical study conducted by Newberry (2018) shows that there are more than 330 million active users on Twitter.

Research in news analysis, in general, is abundant, but research in news and (Twitter) translation, in particular, remains scant (Conway \& Bassnett, 2006; Bielsa \& Bassnett, 2009). Jehl et al., (2012) state that:

Among the various social media platforms, microblogging services such as Twitter have become popular communication tool. This is due to the easy accessibility of microblogging platforms via internet or mobile phones and due to the need for a fast mode of communication, that microblogging satisfies . (p. 410)

Accordingly, Twitter translation has received little attention about Arabic despite the excessive existence of retweeting and reposting tweets that are originally posted in other languages including English.

This paper, therefore, intends to investigate the translation techniques used in translating and reformulating Trump's tweets in Arabic. It is, therefore, hypothesized that Trump's tweets are not translated accurately due to different factors including unfamiliarity of translation techniques, the unfamiliarity of the symbols used in Twitter, and the translator's/agency's ideology. The approach presented in this paper aims to identify the translation techniques used and the extent to which the Arab online agencies succeeded in conveying Trump's tweets to the Arab readers.

\section{Twitter and Its Language}

Twitter is one of the widely used social networks in the new millennium used by ordinary people and politicians alike. It is defined as one of the widespread online news and social networking platforms where users can post and interact with messages, 'tweets', restricted to 140 characters. There are about 500 million tweets are posted everyday by users in more than forty different languages (Mallek et al., 2017). Twitter messages are short and simultaneous. "Twitter users form a social network by 'following' the updates of other users, either reciprocal or oneway", Jehl et al. (2012, p. 410). Accordingly, only registered users can post tweets while 
unregistered can only read them. Interestingly enough is how rapid and scan-friendly it is: we can track hundreds of Tweeters and read them every day.

Because of the fact that Twitter allows only 140 characters in each tweet, Twitters tend to use acronyms, symbols, and abbreviations to save space. Accordingly, they use bro to replace brother, btw instead of by the way, lol to mean laughing out loud, etc. Table 1 shows the widely used symbols and their explanations in brief (cf. https://nobullying.com/twitter-symbols/):

Table 1: Symbols Used in Twitter

\begin{tabular}{|l|l|}
\hline \multicolumn{1}{|c|}{$\begin{array}{c}\text { The Twitter } \\
\text { Symbol }\end{array}$} & \multicolumn{1}{c|}{ Its Meaning } \\
\hline Hashtags (\#) & $\begin{array}{l}\text { Hashtag is probably the most famous of all Twitter symbols. The \# sign is } \\
\text { used to identify certain topics, keywords, events or by companies (e.g. \#FB) } \\
\text { in every official tweet. It is a link that connects you to other topics or tweets } \\
\text { that mentioned the same keyword. }\end{array}$ \\
\hline $\begin{array}{l}\text { Verification } \\
\text { symbol: }\end{array}$ & $\begin{array}{l}\text { It works to establish authenticity of highly sought Tweeters in music, acting, } \\
\text { fashion, journalism, media, literature, religion and politics. }\end{array}$ \\
\hline At symbol (@) & $\begin{array}{l}\text { If you add @ before any username; you can click on it, examine the profile } \\
\text { and any tweet will be sent directly to that user. }\end{array}$ \\
\hline Cashtags (\$) & $\begin{array}{l}\text { It is a clickable ticker symbol \$ added to companies' names (e.g. \$FB) so } \\
\text { that users can look up their finances and stocks. }\end{array}$ \\
\hline Caret/hat (^) & $\begin{array}{l}\text { It reflects a tweet sent by an individual representative of a group, an } \\
\text { organization or a company. }\end{array}$ \\
\hline Retweet: & $\begin{array}{l}\text { Retweet is another popular Twitter symbol. People retweet all the time, from } \\
\text { each other, from celebrities, from famous companies and brands. }\end{array}$ \\
\hline Reply: & $\begin{array}{l}\text { This is a method of communicating with a fellow Twitter user without using } \\
\text { the @ symbol. }\end{array}$ \\
\hline Favorite: & $\begin{array}{l}\text { To retweet or to favorite that is the question. Most people do not understand } \\
\text { the difference between favoring a tweet and retweeting it. Also many Twitter } \\
\text { users are curious as to the significance of these two symbols. }\end{array}$ \\
\hline
\end{tabular}

\section{Vinay and Darbelnet's Translation Strategies}

Translation strategies are defined as the procedures that lead to the optimal solutions of translation problems (Krings, 1986; Lorscher, 1991). Vinay and Darbelnet (1958/1995), who carried out a comparative stylistic analysis of French and English looking at texts in both languages, suggested various translation procedures. These procedures are not only used to solve translation problems in French-English translation but also applicable when translating between 
other languages. They (1995) identify two general translation strategies: direct translation and oblique translation. Each of which comprises some procedures: direct translation (borrowing, calque, and literal translation) and oblique translation (transposition, modulation, equivalence, and adaptation). The following is a discussion of each procedure along with English-Arabic examples:

\section{Direct Translation Procedures:}

A) Borrowing: borrowing is referred to when a source language (SL) word or phrase is directly transferred to the target language (TL). This word or phrase is used in a naturalized form, i.e. to suit the pronunciation and grammatical rules of the TL. Examples

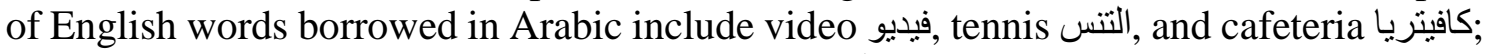
and Arabic words borrowed in English زكاة Zakat, حلال Halal, انتفاضة Intifada, etc.

B) Calque: calque is a special kind of borrowing where the SL expression is transferred literally into the TL. Newmark (1988) calls this procedure through-translation, e.g., play with fire يلعب بالنار. In addition, calque is widely used by translators in translating the names of international organizations. Calque TL expression concerns the imitation of the SL manner of expression. For example, play a role يلعب دورا, North Atlantic Treaty Organization (NATO) منظمة حلف الثمال الأطلسي Food and Agricultural Organization (FAO) منظمة الأغذية والزراعة United Nations Educational, Scientific, and Cultural Organization منظمة الأمم المتحدة للتربية والثقافة و العلوم (UNESCO).

C) Literal Translation: Literal translation is a word-for-word translation described by Vinay and Darbelnet (1995) as being most common when translating between languages that belong to the same family and culture. They argue that "literalness should only be sacrificed because of structural and metalinguistic requirements and only after checking that the meaning is fully preserved." However, Munday (2001, p. 57) states that literal translation might "be unacceptable because it: (a) gives a different meaning; (b) has no meaning; (c) is impossible for structural reasons; (d) 'does not have a corresponding expression within the metalinguistic experience of the TL'; (e) corresponds to something at a different level of language." It is usually used with simple structures when translating from English into Arabic, as in Smith went to school yesterday ذهب سميث إلى المدرسة أمس John likes football جون يحب كرة القدم.

\section{Oblique Translation Procedures}

A) Transposition: Transposition is a translation procedure that is used when changing one part of speech for another without changing the tense (Vinay\& Darbelnet, 1995). Transposition is a strategy sometimes used for stylistic reasons and "simply shows a very good command of the target language," (Vinay\& Darbelnet, 1995). It works in different ways such as (a) singular to plural, e.g., car manufacturing صناعة السيارات; (b) verb to noun, e.g., Jack likes to cook on Sunday يحب جاك الطبخ يوم الأحد:; (c) verb to noun, e.g., To free a slave تحرير رقبة 
B) Modulation: Modulation changes the view point of the SL. Vinay and Darbelnet (1995, p. 246) state that modulation is "the touch stone of a good translator". Modulation is subdivided into different categories such as (a) active for passive, e.g., it was revealed by the BBC reporter that... كثنف مر اسل قناة البي بي سي أن; (b) positive for لداينا وقت كل double negative, e.g., we have time for negotiations, but it is not unlimited للمفاوضات إلا أنه محدود (c) cause for effect, e.g., he was obeyed كان يفرض الطاعة (d) part for whole, e.g., the village will establish a new school next year سيفتح سكان القرية مدرسة جديدة السنة المقبلة.

C) Equivalence: Equivalence is used to "refer to cases where languages describe the same situation by different stylistic or structural means" (Munday, 2001, p. 58). It is very useful in translating non-literal semantic features such as idioms and proverbs as in, as white as snow أبيض كالحليب; he got nothing at the end عاد بخفي حنين.

D) Adaptation: Adaptation involves a change in the cultural reference when a specific situation in a language does not exist in another, e.g. as rich as Croesus يملك مال قارون.

\section{Nida's Proposed Strategies}

Nida (1964) proposes three translation strategies: addition, subtraction, and alteration. These strategies are used to adjust the form of the message to the characteristics of the structure of the target language; to produce semantically equivalent structures; to generate appropriate stylistic equivalences; and/or to produce an equivalent communicative effect, (Molina \& Albir, 2002). These strategies are defined and exemplified as follows:

a) Addition: Nida lists different circumstances that might oblige a translator to make an addition: to clarify an elliptic expression, to avoid ambiguity in the target language, to change a grammatical category (transposition), to amplify implicit elements, and/or to add connectors.

Three British soldiers are reportedly killed yesterday by Taliban in Afghanistan, the BBC has learnt.

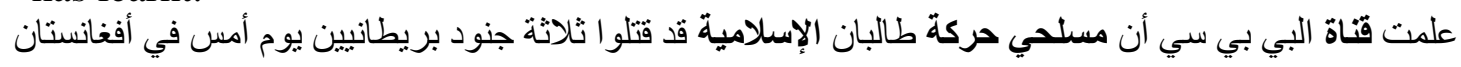

The above example shows two additions: قناة and Tسلحي حركة طالبان الإسلامية These two additions do not change the meaning but they do clarify it. Accordingly, translation by addition is a useful technique but it should be used properly, (Zagood, 2014).

b) Subtraction: Nida lists four situations where the translator should use this procedure, in addition to when it is required by the TL: unnecessary repetition, specified references, conjunctions and adverbs. For example, the name of God appears thirty-two times in the thirty-one verses of Genesis. Nida suggests using pronouns or omitting God.

c) Alteration: some changes are needed especially where there is incompatibility between the two languages. Alteration as a translation technique includes 
1) Changes due to the problems caused by transliteration when a new word is introduced from the source language.

2) Changes due to the structural differences between the two languages, changes in the word order and/or grammatical categories are good examples.

3) Changes due to semantic misfits, especially with idiomatic expressions. (Molina \& Albir, 2002).

\section{Research Methodology}

This section presents the selection and justification for the choice of data used in this study. As well known, one of the controversial public politicians who always tweets are the American President, Donald Trump. He sometimes tweets on controversial topics and presidential decrees. These tweets are translated and reposted in other languages including Arabic. Translators use different translation strategies to convey the intended meanings of Trump's tweets to other languages. This paper investigates and analyzes the strategies used in translating Trump's tweets into Arabic. The translations to be analyzed are selected randomly from different Arab online news agencies.

Therefore, to collect data for this study, eight of Trump's tweets during his first month of the presidency, January $19^{\text {th }}, 2017$ to February $20^{\text {th }}, 2017$, were randomly selected. Two Arabic translations for each of the selected tweets were also chosen randomly from the Arab online media, to see how the Arab media conveys Trump's ideas to the Arab readers. A comparison between the two translations of each tweet is undertaken to see if there is a difference in meaning between the two translations. In addition, an analysis of the translation strategies adopted in each translation is also conducted to see how Arab translators use the translation strategies suggested by Vinay and Darbelnet (1958/1995) and Nida (1964).

The reason for choosing Trump's tweets for analysis is due to his controversial character as well as being chosen as the TIME's person of the year 2016 (Time, 2016); and above all, being the president of the US. Furthermore, Vinay and Darbelnet (1958/1995) and Nida (1964) suggest different translation strategies so that translators find them useful when transferring the message from one language to another. Therefore, eight of Trump's tweets have been chosen to see how they were translated into Arabic, and how helpful Vinay and Darbelnet's model and Nida's proposed strategies are. The analysis would be through tabulating each tweet along with its two translations in order to investigate the degree of equivalency and to which extent Vinay and Darbelnet's and Nida's strategies were adopted and succeeded in conveying the meaning. Accordingly, the methodology presents the translation techniques and procedures in light of the theoretical framework set in the previous sections.

\section{Analysis of the Study Data}

As it was mentioned earlier, the analysis in this section is based on Vinay and Darbelnet's and Nida's translation strategies. It is shown from the above-mentioned examples that the proposed strategies are used in translation irrespective of the two languages in question. The qualitative approach is used in analyzing the data collected. The analysis consists of tabulating each tweet 
AWEJ for Translation \& Literary Studies Volume, 3 Number 1. February 2019

An Analytical Study of the Strategies Used in Translating Trump's Tweets Zagood

along with its two translations. The table is followed by an analysis of the two translations. Williams and Chesterman $(2007$, p. 7) state that "the analysis of translated texts involves a textual comparison of a translation with its original." The analysis below shows to what extent Vinay and Darbelnet's and Nida's strategies were used appropriately in translating Trump's tweets into Arabic. Thus, the following is the analysis of the randomly selected tweets and their translations from randomly selected Arab online news websites:

Table 2: Tweet one posted on Feb 7, 2017

\begin{tabular}{|c|c|c|}
\hline Trump's Tweet (ST) & Arabic Translation 1 (TT) & Arabic Translation 2 (TT) \\
\hline $\begin{array}{l}\text { I don't know Putin, have no } \\
\text { deals in Russia, and the haters } \\
\text { are going crazy - yet Obama } \\
\text { can make a deal with Iran, \#1 } \\
\text { in terror, no problem! }\end{array}$ & 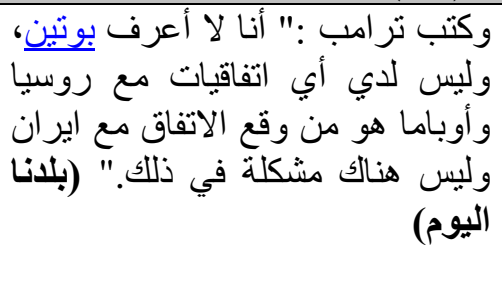 & 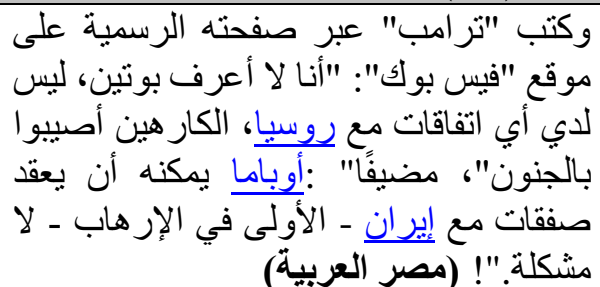 \\
\hline
\end{tabular}

The tweet above carries two main ideas: Trump's negation of having dealt with Russia, and the irony in his reference to the nuclear agreement with Iran.

In the first translation, Nida's subtraction (omission) was adopted in two cases: and the haters are going crazy and \#1 in terror. Both subtractions could not be accepted because they affect the meaning in the sense that the irony is ignored as well as neglecting Trump's view of Iran. Such subtraction might also be attributed to the translator's (agency's) ideology, (cf. Venuti, 2008; Lopez \& Caro, 2014; and Ethelb, 2016). In the second translation, in contrast, these two

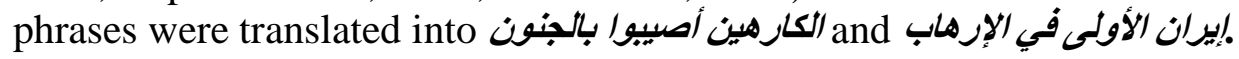

Table 3: Tweet two posted on Feb 6, 2017

\begin{tabular}{|c|c|c|}
\hline Trump's Tweet (ST) & Arabic Translation 1 (TT) & Arabic Translation 2 (TT) \\
\hline $\begin{array}{l}\text { Any negative polls are fake } \\
\text { news, just like the CNN, } \\
\text { ABC, NBC polls in the } \\
\text { election. Sorry, people want } \\
\text { border security and extreme } \\
\text { vetting. }\end{array}$ & 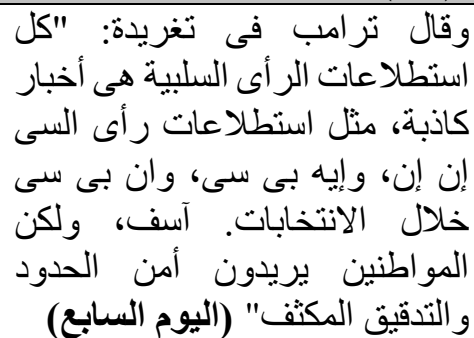 & 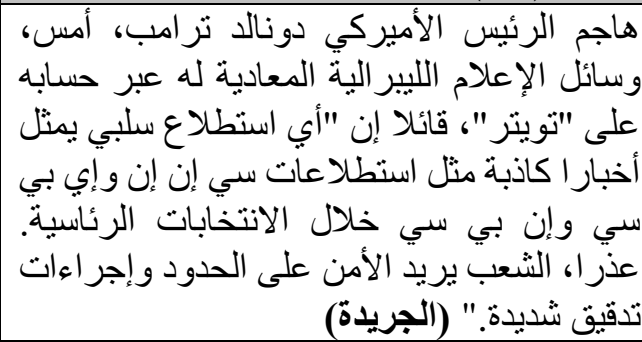 \\
\hline
\end{tabular}

In this tweet, Trump accuses the negative polls on some TV channels of being fake insisting on the people's need for security on the borders and the extreme vetting.

In both translations, the acronymic names of the TV channels (CNN, ABC, NBC) were

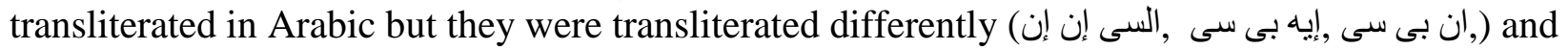
وسائل (إن بي سي ,إيه بي سي ,سي إن إن) In the second translation, there was also a use of addition where is added. This addition claims that such TV channels were hostile to Trump.

Arab World English Journal for Translation \& Literary Studies 
However, no clear indication in the tweet for such claim unless the translator brings this information from other resources.

Table 4: Tweet three posted on Feb 8, 2017

\begin{tabular}{|c|c|c|}
\hline Trump's Tweet (ST) & Arabic Translation 1 (TT) & Arabic Translation 2 (TT) \\
\hline $\begin{array}{l}\text { If the U.S. does not win this case as it } \\
\text { so obviously should, we can never } \\
\text { have the security and safety to which } \\
\text { we are entitled. Politics! }\end{array}$ & 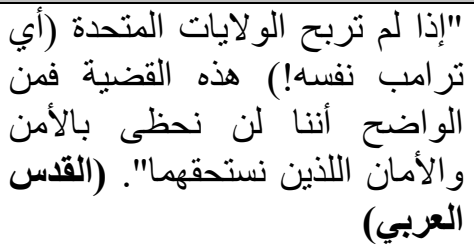 & 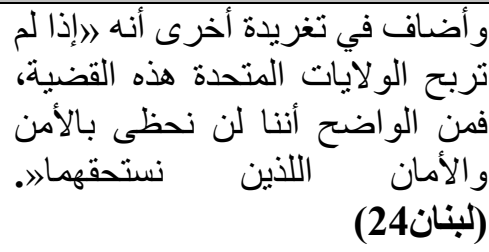 \\
\hline
\end{tabular}

This tweet shows Trumps view on the case raised to the court regarding the ban of seven countries' nationals from entering the US.

In the first translation, أي ترامب نفسه was unnecessarily added. This addition reflects the translator's belief that the case represents Trump alone not US as a country. In both translations, as it so obviously should and politics were not translated.

Table 5: Tweet four posted on Feb 4, 2017

\begin{tabular}{|c|c|c|}
\hline Trump's Tweet (ST) & Arabic Translation 1 (TT) & Arabic Translation 2 (TT) \\
\hline $\begin{array}{l}\text { Because the ban was lifted by a } \\
\text { judge, many very bad and } \\
\text { dangerous people may be } \\
\text { pouring into our country. A } \\
\text { terrible decision. }\end{array}$ & 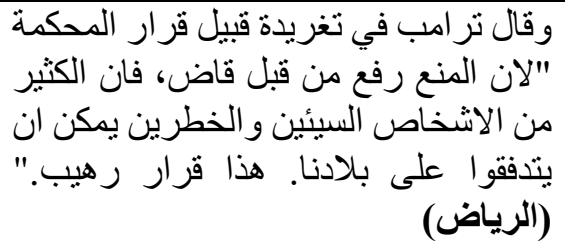 & 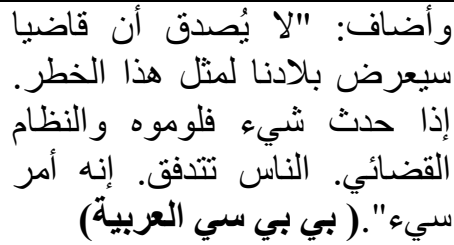 \\
\hline
\end{tabular}

In this tweet, Trump warns that many bad and dangerous people may enter the US if the ban is lifted and describes the decision of being terrible.

The literal translation was used in the first translation transferring the meaning literally to the target language, Arabic. In the first translation; the translator, influenced by the SL (English), used an exotic phrase من قبل which is not preferable in Arabic. In the second translation, modulation and free translation strategies were also used. However, there is some kind of ambiguity in the target text: it is unclear to whom/what the resumptive pronoun in فلوموه refers to, i.e. what the antecedent of this pronoun is.

Table 6: Tweet five posted on Jan 29, 2017

\begin{tabular}{|c|c|c|}
\hline Trump's Tweet (ST) & Translation 1 (TT) & Translation 2 (TT) \\
\hline $\begin{array}{l}\text { Our country needs strong } \\
\text { borders and extreme vetting, } \\
\text { NOW. Look what is }\end{array}$ & 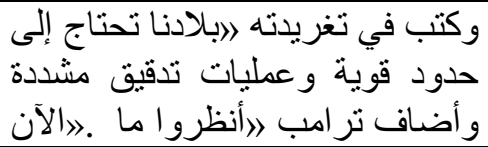 & 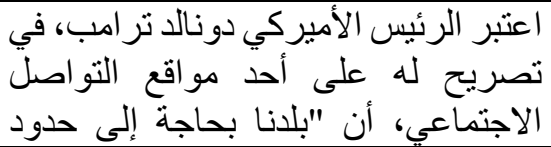 \\
\hline
\end{tabular}

Arab World English Journal for Translation \& Literary Studies

ISSN: 2550-1542 | www.awej-tls.org 
AWEJ for Translation \& Literary Studies Volume, 3 Number 1. February 2019

An Analytical Study of the Strategies Used in Translating Trump's Tweets

Zagood

\begin{tabular}{|c|c|c|}
\hline $\begin{array}{l}\text { ng all over Europe } \\
\text { deed, the world - a } \\
\text { mess! }\end{array}$ & 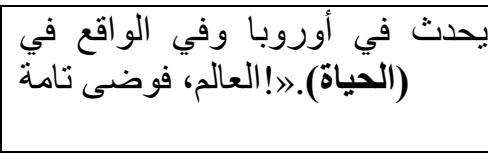 & 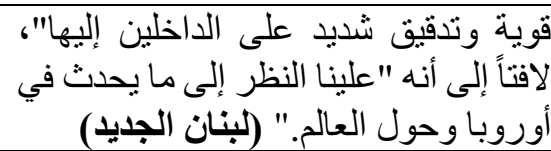 \\
\hline
\end{tabular}

In this tweet, Trump stresses the need for extreme vetting on the US borders and refers to what happens in Europe and elsewhere in the world.

و أضاف In both translations, the translators divided this tweet into two quotes each adding لاففتا إلى أنه and In the second translation only, subtraction is used when a horrible mess is omitted. Accordingly, both addition and subtraction were used.

Table 7: Tweet six posted on Feb 3, 2017

\begin{tabular}{|c|c|c|}
\hline Trump's Tweet (ST) & Arabic Translation 1 (TT) & Arabic Translation 2 (TT) \\
\hline $\begin{array}{l}\text { Iran is playing with } \\
\text { fire - they don't } \\
\text { appreciate how "kind" } \\
\text { President Obama was } \\
\text { to them. Not me! }\end{array}$ & 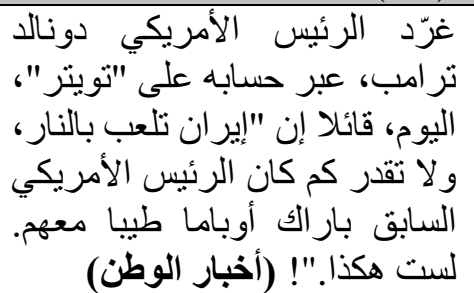 & 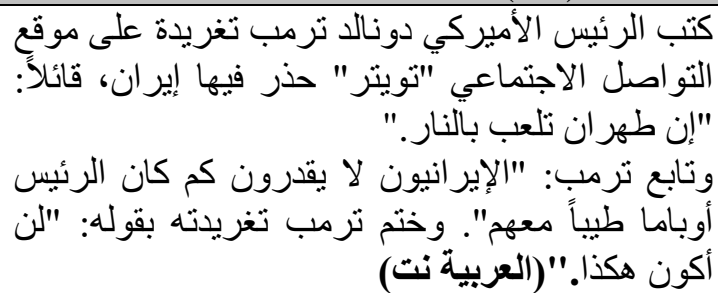 \\
\hline
\end{tabular}

In this tweet, Trump warns Iran of producing nuclear weapons saying that they are playing with the fire and he is not going to deal with them kindly as Obama did.

In both translations, calque is used in translating playing with fire as this idiom is used in both languages meaning that someone is doing something dangerous. In the second translation, the statement is divided to smaller units adding some expressions (وختم ترمب تغريدنه and وتابع ترمب بقوله to connect the ideas.

Table 8: Tweet seven posted on Feb 2, 2017

\begin{tabular}{|c|c|c|}
\hline Trump's Tweet (ST) & Arabic Translation 1 (TT) & Arabic Translation 2 (TT) \\
\hline $\begin{array}{l}\text { If U.C. Berkeley does not } \\
\text { allow free speech and } \\
\text { practices violence on } \\
\text { innocent people with a } \\
\text { different point of view - NO } \\
\text { FEDERAL FUNDS? }\end{array}$ & 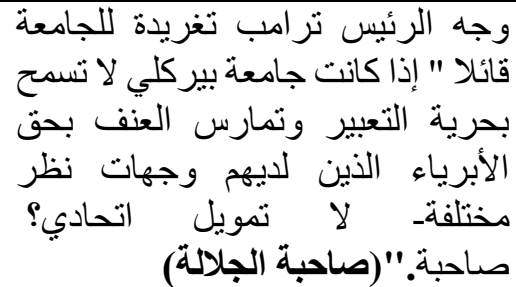 & 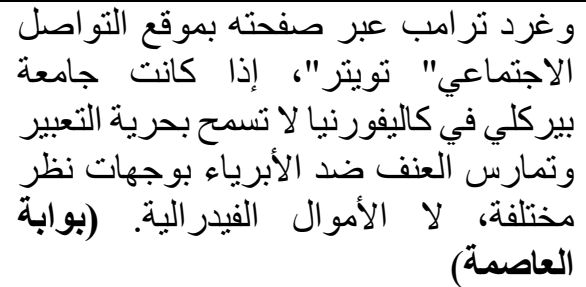 \\
\hline
\end{tabular}

In this tweet, Trump warns Berkeley University that he would stop the federal funding if they do not allow the freedom of speech and practice violence on people with different views.

Arab World English Journal for Translation \& Literary Studies 
In both translations, the word جامعة is added so that all readers understand what Berkeley is. This addition is needed in such context as not all readers know that Berkeley is a university. In the second translation, no federal funds is translated literally with borrowing federal in Arabic resulting لا الأمو ال الفيدر الية which is unclear.

Table 9: Tweet eight posted on Feb 11, 2017

\begin{tabular}{|c|c|c|}
\hline Trump's Tweet (ST) & Arabic Translation 1 (TT) & Arabic Translation 2 (TT) \\
\hline $\begin{array}{l}\text { Our legal system is } \\
\text { broken! "77\% of refugees } \\
\text { allowed into U.S. since } \\
\text { travel reprieve hail from } \\
\text { seven suspect countries." } \\
\text { (WT) SO DANGEROUS! }\end{array}$ & 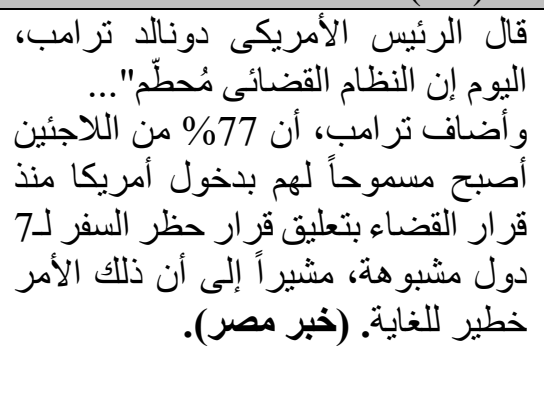 & 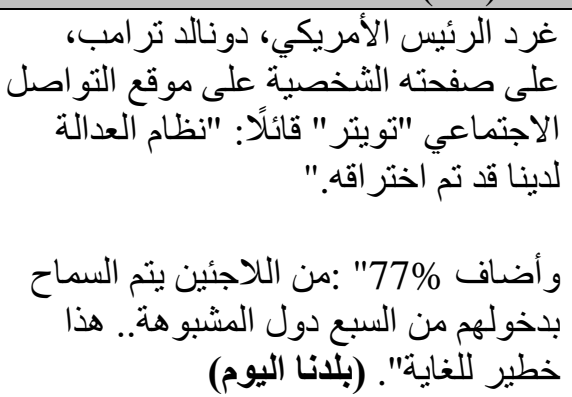 \\
\hline
\end{tabular}

In this tweet, Trump criticizes the judicial system in the country saying it is broken as it allows the citizens from the seven suspect countries to enter into U.S.

In the first translation, both addition and literal translation techniques were used. Phrases like مشيرا إلى أن ذلك الأمر and were added. Legal system is broken was literally translated. In the second translation, both addition and subtraction were used. أضیى و و while since travel reprieve hail was omitted.

\section{Findings}

Having compared the Arabic translations of Trump's tweets and analyzed them, the following are some findings:

1. Trump's tweets are translated and reposted in many Arab online media websites.

2. Arab translators use various translation strategies including Vinay and Darbelnet's (1958/1995) and Nida's (1964) proposed techniques to convey Trump's tweets to Arab readers.

3. Some translation techniques were correctly used while others were not.

4. Nida's additions and subtractions were the widely used strategies to convey the meaning and overcome the gaps between the two languages.

5. In some translations, phrases were deleted because of misunderstanding of the symbols used in twitter or because of the translator's/agency's ideology.

6. There was some sort of negative transfer between the two languages.

\section{Conclusion}

This paper looked at Twitter as a widely growing social media network used by ordinary people and politicians alike. It shed some light on the language and symbols used in tweets. It 
AWEJ for Translation \& Literary Studies Volume, 3 Number 1. February 2019

An Analytical Study of the Strategies Used in Translating Trump's Tweets

Zagood

mainly aimed at comparing and investigating the translations of some of Trump's tweets into Arabic. It also aimed to see how Arab news agencies convey Trump's tweets to the Arab reader. To reach this end, eight of Trump's tweets at his first month of presidency along with two Arabic translations for each tweet in some Arab online news agencies have been randomly selected for comparison and analysis.

The analysis showed that Trump's tweets are translated and reposted every day in the Arab online news websites. Translators use different translation strategies to convey the tweets' meanings to Arab readers. Some strategies were used appropriately while others were not. Thus, unsurprisingly, the results of this study corroborate the postulated hypothesis and provide clear evidence that the Arabic translations of some tweets in some Arab online news agencies are to a certain extent inaccurate. Such inaccuracy is attributed to the misunderstanding of some symbols used in Twitter, disuse of translation strategies, and translator's/news agency's ideologies.

\section{About the Author:}

Mohammed Zagood is an Assistant Prof. of Translation Studies at UAE University. He got his PhD from Durham University in 2012. Currently, he is teaching translation and interpreting courses at the UAEU. Since 2012, Dr. Zagood has participated in a number of international conferences and published some articles in journals and conference proceedings. ORCID ID: https://orcid.org/0000-0002-7786-2667

\section{References}

Barton, D. \& Lee, C. (2013). Language Online: Investigating Digital Texts and Practices. London and New York: Routledge.

Bielsa, E. \& Bassnett, S. (2009). Translation in Global News. London: Routledge.

Conway, K. \& Bassnett, S. (eds). (2006). Translation in Global News: proceedings of the conference held at the University of Warwick. Warwick: University of Warwick.

Ethelb, H. (2016). Mediating Ideology in News Headlines: A Case Study of Post-Revolution Egypt. Arab World English Journal. 5, 108-123.

Jehl, L. et al. (2012). 'Twitter Translation Using Translation-Based Cross-Lingual Retrieval'. In Proceedings of the Seventh Workshop on Statistical Machine Translation (WMT'12), Montreal, Quebec, Canada.

Krings, H.P. (1986). Translation problems and translation strategies of advanced German learners of French. In J. House, \& S. Blum-Kulka (eds.), Interlingual and intercultural communication Tubingen: Gunter Narr. 263-75.

Lopez, A. \& Caro, M. (2014). The Impact of Translator's Ideology on the Translation Process: A Reaction Time Experiment. In Minding Translation, Special Issue No. 1, 247-271.

Lorscher, W. (1991). Translation performance, translation process and translation strategies. Tubingen: Gunter Narr.

Mallek, F. et al (2017). Arabic Social Media Analysis and Translation. $3^{\text {rd }}$ International Conference on Arabic Computational Linguistics, ACLing 2017, (5-6 Novermber. Dubai. 298-303.

Arab World English Journal for Translation \& Literary Studies 
AWEJ for Translation \& Literary Studies Volume, 3 Number 1. February 2019

An Analytical Study of the Strategies Used in Translating Trump's Tweets

Zagood

Molina, L. \& Albir A. (2002). 'Translation Techniques Revisited: A Dynamic and Functionalist Approach'. Meta Vol. 47. No. 4.

Munday, J. (2001). Introducing Translation Studies: Theories and Implications. London and New York: Routledge.

Newberry,C. (2018). 28 Twitter Statistics All Marketers Need to Know in 2018. Available at https:/blog.hootsuite.com/twitter-statistics/. (Accessed 06.01.2018).

Newmark, P. (1988). A Textbook of Translation. London: Prentice Hall.

Nida, E. (1964) Toward a Science of Translation. Leiden: Brill.

Organisation for Economic Co-operation and Development (2010). News in the Internet Age: New Trends in News Publishing. OECD Publishing.

Time. http://time.com/time-person-of-the-year-2016-donald-trump/. (Accessed 27.10.2018).

Trump, D. Tweets. Available at Donald J. Trump @ realDonaldTrump. (Accessed in 15.02.2017).

Trump, D. Tweet. Translated by Baladnaelyoum. Available at http://www.baladnaelyoum.com/329267. (N.P). 2017. (Accessed in 20.02.2017).

Trump, D. Tweet. Translated by Masralarabia. Available at http://m.masralarabia.com (N.P). 2017. (Accessed in 20.02.2017).

Trump, D. Tweet. Translated by Alarabiya. Available at http://www.alarabiya.net/ar/arab-andworld/american-elections-2016/2017/02/03. (N.P). 2017. (Accessed in 20.02.2017).

Trump, D. Tweet. Translated by Lebanon24. Available at http://www.lebanon24.com/articles/1486772427243197500/. (N.P). 2017. (Accessed in 20.02.2017).

Trump, D. Tweet. Translated by Alquds. Available at http://www.alquds.co.uk/?p=671944. (N.P). 2017. (Accessed in 20.02.2017).

Trump, D. Tweet. Translated by Aljarida. Available at http://www.aljarida.com/articles/1486401996301781700/. (N.P). 2017. (Accessed in 20.02.2017).

Trump, D. Tweet. Translated by Alriyadh. Available at http://www.alriyadh.com/1568882(N.P). 2017. (Accessed in 20.02.2017).

Trump, D. Tweet. Translated by Youm7. Available at http://www.youm7.com/story/2017/2/6(N.P). 2017. (Accessed in 20.02.2017).

Trump, D. Tweet. Translated by BBC Arabic. Available at http://www.bbc.com/arabic/world38872748(N.P). 2017. (Accessed in 20.02.2017).

Trump, D. Tweet. Translated by Alhayat. Available at http://www.alhayat.com/Articles/19879823(N.P). 2017. (Accessed in 20.02.2017).

Trump, D. Tweet. Translated by New Lebanon. Available at http://www.newlebanon.info/lebanon-now/301954. (N.P). 2017. (Accessed in 22.02.2017).

Trump, D. Tweet. Translated by Alwatan News. Available at http://www.elwatannews.com/news/details/1844564. (N.P). 2017. (Accessed in 20.02.2017).

Trump, D. Tweet. Translated by Khabar Masr. Available at http://www.khabarmasr.com/news/get_news/392255/. (N.P). 2017. (Accessed in 22.02.2017).

Arab World English Journal for Translation \& Literary Studies 
AWEJ for Translation \& Literary Studies Volume, 3 Number 1. February 2019

An Analytical Study of the Strategies Used in Translating Trump's Tweets

Zagood

Trump, D. Tweet. Translated by Majesty News. Available at http://majestynews.com/index.php/ar/2015-07-05-09-19-62/7187. $\quad$ (N.P). 2017. (Accessed in 20.02.2017).

Trump, D. Tweet. Translated by Alasema. Available at http://www.al3asma.com/230820. (N.P). 2017. (Accessed in 20.02.2017).

Twitter Symbols. https://nobullying.com/twitter-symbols/. (Accessed in 20.02.2017).

Venuti, L. (2008). The Translator's Invisibility: A History of Translation. London and New York: Routledge.

Vinay, J. \& J. Darbelnet (1958/1995) Comparative stylistics of French and English: a methodology for translation (translated and edited by J. Sager \& M. J. Hamel), Amsterdam \& Philadelphia: John Benjamin's Publishing Company.).

Williams, J. \& Chesterman, A. (2002). The Map: A Beginner's Guide to Doing Research in Translation Studies. Manchester and New York: St Jerome Publishing.

Zagood, M. (2014a). 'Commented Translation: a New Perspective in Translation Teaching Methodology in Libya' In Baur, W. et al (eds). Man vs. Machine, Berlin, 4-6 August 2014. Berlin: BDU Fachverlag, Vol. II, pp 1040-1047.

Arab World English Journal for Translation \& Literary Studies 